
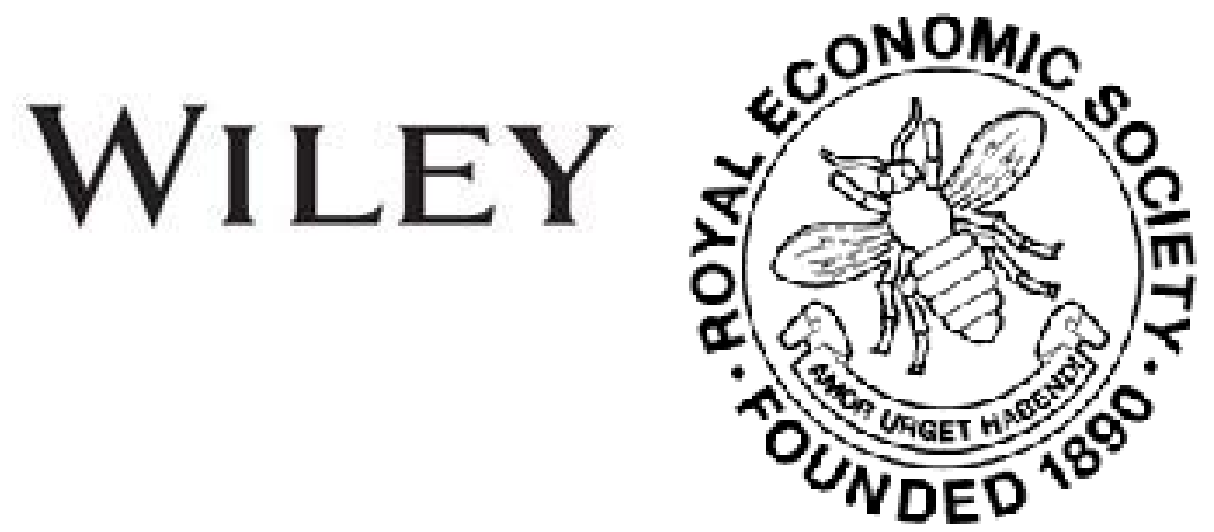

The Present Ideals of Co-operation

Author(s): X

Source: The Economic Journal, Vol. 12, No. 45 (Mar., 1902), pp. 29-41

Published by: Wiley on behalf of the Royal Economic Society

Stable URL: http://www.jstor.org/stable/2957022

Accessed: 17-04-2016 23:09 UTC

Your use of the JSTOR archive indicates your acceptance of the Terms \& Conditions of Use, available at

http://about.jstor.org/terms

JSTOR is a not-for-profit service that helps scholars, researchers, and students discover, use, and build upon a wide range of content in a trusted digital archive. We use information technology and tools to increase productivity and facilitate new forms of scholarship. For more information about JSTOR, please contact support@jstor.org.

Wiley, Royal Economic Society are collaborating with JSTOR to digitize, preserve and extend access to The Economic Journal 


\section{THE PRESENT IDEALS OF CO-OPERATION}

From the report on Co-operation recently issued by the Labour Department of the Board of Trade (Report on Workmen's Co-operative Societies in the United Kingdom. Cd. 698 of 1901. Price $1 s .2 \frac{1}{2} d$.) we learn that the total number of the members of our workmen's co-operative societies of all classes at the end of 1899 was $1,681,342$, forming $4 \cdot 1$ per cent. of the population of the United Kingdom, and that the business transacted by these societies in that year was of the aggregate amount of $£ 129,533,958 .^{1}$

In order to appreciate the exact significance of the co-operative movement it is necessary to inquire what are the distinguishing principles characterising those forms of commerce and industry which are classed under the general title of "Co-operation." For reasons, which will shortly be apparent, the answer to this question can only be given with adequate lucidity by means of an historical retrospect.

The earliest reported attempt by British workmen to form a co-operative trading society dates back to 1795 , when (as stated in a petition addressed to the Corporation of Hull) the "poor inhabitants of the said town," in consequence of the " exorbitant, price of flour," and in order to protect themselves from the "invasions of covetous and merciless men," "entered into a subscription, each subscriber to pay $1 s .1 d$. per week for four weeks, and $6 d$. per week for four weeks more, which is $6 s .4 d$. each, for the purpose of building a mill, which is to be the subscribers', their heirs', executors', administrators' and assigns' for ever, in order to supply them with flour."

As the result of this combination, the Hull Anti-Mill Society's mill was opened on June 7th, 1797, the original number of members being 1,435 ; and its establishment was followed by the

${ }_{1}$ Including the business done by the banking department of the English Wholesale Society. 
erection of a second co-operative corn-mill in the same town, and of others at Whitby, Devonport, and Sheerness, and by the formation of several bread-baking societies in Scotland. Little progress was, however, made in the spread of Co-operation until after the repeal of the Combination Laws in 1824.

As a consequence of the teaching and activities of Robert Owen and his co-workers at this period, many co-operative societies were established throughout the country, their objects being stated in The Co-operator of October, 1828, as follows :-

I. The OBjects of such a society are, first, the mutual protection of the members against POVERTY; secondly, the attainment of a greater share in the comforts of life; thirdly, the attainment of INDEPENDENCE by means of a common capital.

II. The Means of obtaining these objects.-These means consists, first in a weekly subscription, of not less than sixpence to a common capital, and secondly, in employing those subscriptions in a different way to what is usually done-namely, not in investment but in trade; thirdly, when they have accumulated sufficiently, in manufacturing for the Society; and lastly, when the capital has still further accumulated, in the purchase of land, and living upon it in community.

After describing various other plans adopted by workmen for improving their position and showing the superiority of the Cooperative Society, or "Working Union," The Co-operator continues :-

The Union then will begin with a shop; to manage this shop they must have an agent; this agent must be a member; he will be chosen by the Society; he will keep regular accounts as is done in all business. Three other members will be appointed as trustees, to receive the weekly subscriptions, to superintend the agent, and to audit his accounts; this will be done weekly, that all may know the state of the Society; and the trustees being changed occasionally, all will become acquainted with the mode of transacting business. At first, the capital of the Society will be small, the shop will not be able to supply the members with all the articles of consumption they may want. As the capital increases, this will be done more perfectly. But as the wants of the members are limited, there will be a time when scapital will exceed what the shop requires. This will happen in less than one year after the Society is formed, even though the weekly subscriptions should be as low as threepence. When this period arrives, the Society will ask themselves this question-What shall we do with our surplus capital? The answer will be-employ one of your own members to manufacture shoes, or clothes, \&c., \&c., for the rest; pay him the usual wages, and give the profits to the common capital. In this way they will proceed, as the capital increases, to employ one member after another, either to manufacture articles consumed by the members, or by the public.

Beginning to manufacture for the members, the sale is sure. When the capital is able to produce more goods than the members can consume, they must manufacture those articles which are in demand by the public at large. 
That the objects stated by The Co-operator were those generally accepted by the co-operative societies of that period, is clearly shown by a series of "Fundamental Rules and Regulations as the only constitutional basis upon which societies can be permanently and successfully established," which were adopted by the Congress of Delegates from the Co-operative Societies of Great Britain and Ireland, held in London in 1832 (Report of the Third Congress of Delegates from the Co-operative Societies of Great Britain and Ireland, pp. 102-3), and which were as follows :-

1. Let it be universally understood that the grand ultimate object of all co-operative societies, whether engaged in trading, manufacturing, or agricultural pursuits, is community on land.

2. To effect this important purpose a weekly subscription, either in money, goods, or labour-from a penny to any other amount agreed upon-is indispensably necessary, to be continued from year to year until a capital sufficient to accomplish the object of the Society be accumulated.

3. The next preliminary step to be pursued as auxiliary to the former will be for the Society to purchase, at wholesale price, articles of ordinary consumption of the most genuine description, in order to be retailed at the market prices for the purpose of further accumulation. The adoption of these instructions will, of course, be regulated by the circumstances and inclinations of particular societies.

3. We would observe that the immediate benefit derivable from these societies, in their successful approximation to community, are the mutual employment of members, the establishment of schools for the education of children, and of libraries and reading-rooms for adults.

5. In order to ensure, without any possibility of failure, the successful consummation of these desirable objects, it is the unanimous decision of the delegates here assembled that the capital accumulated by such associations should be rendered indivisible, and any trading societies formed for the accumulation of profits with the view to the merely making a dividend thereof at some future period cannot be recognised by this Congress as identified with the co-operative world, nor admitted into that great social family which is now rapidly advancing to a state of independent and equalised community.

6. It is deemed more especially essential in all the trading transactions of co-operative societies, that credit shall be neither taken nor given; as a deviation from this important principle has been the sole cause of the destruction of so many previous societies and thus banefully operated to retard the general progress of co-operation. In order to carry this important measure into successful operation, the Congress recommend that in case of want of employment among the nembers, means should be taken by the Society, if possible, to provide them some employment, as local circumstances may admit. In cases of sickness, should there be no other sources of relief, pecuniary assistance may be given either from the funds belonging to the Society or from individual subscription amongst the members.

7. The Congress is of opinion that it is extremely inimical to the principles of co-operation, and productive of the most injurious consequences to permit an individual who is already a member of one society to become a member of another. 
The principles here set out appear to have been very attractive to workmen for some years; indeed, as early as 1830, it was stated that between 400 and 500 co-operative societies were in existence, and that a society at Huddersfield with 250 members had, starting with a trading capital of $19 s$., in twelve months accumulated $£ 700$, and many of the members were accommodated with permanent employment, while the conditions of others were rapidly improving. They were manufacturing broadcloth, cassimeres, waistcoat pieces, stuffs, and a variety of other articles. (See Sixth Quarterly Report of the British Association for Promoting Co-operative Knowledge, October, 1830.) Nearly all of these societies, however, had but a brief existence.

In 1843 a weavers' strike led to the formation of the Rochdale Equitable Pioneers' Society in Toad Lane, Rochdale, which in 1844 issued the following programme:-

1. The establishment of a store for the sale of provisions, clothing, \&c.

2. The building, purchasing, or erecting a number of homes in which those members desiring to assist each other in improving their domestic and social condition may reside.

3. To commence the manufacture of such articles as the Society may determine upon, for the employment of such members as may be without employment, or who may be suffering in consequence of repeated reductions in their wages.

4. As a further benefit and security to the members of this Society, the Society shall purchase or rent an estate or estates of land, which shall be cultivated by the members who shall be out of employment, or whose labour may be badly remunerated.

5. That, as soon as practicable, this Society shall proceed to arrange the power of production, distribution, education, and government, or in other words, to establish a self-supporting home colony of united interests, and assist other societies to establish such colonies.

6. That, for the promotion of sobriety, a temperance hotel be opened in one of the Society's houses as soon as convenient.

The Rochdale Pioneers, following the example of certain of the earlier societies, adopted in regard to the distribution of their profits the practice now commonly termed the "Rochdale system." This system, which consists in dividing among the persons purchasing from the society, the surplus profits remaining after share capital has received a fixed rate of interest, and which was subsequently adopted by practically all associations of a similar nature, greatly contributed to the success which these "distributive societies" have attained.

While in the earlier societies the usual rule was that members should hold an equal amount of capital, and exercise equal voting power in the society, the Rochdale Pioneers adopted the 
rule that each member must apply for four $£ 1$ shares, and might hold any number not exceeding fifty, to be paid up in full, or by instalments, and by the accumulation of profits until four fully paid-up shares were held, but provided that, as the number of small shareholders increased, members having more than four shares might be compelled to reduce the number of their shares so long as any members held less or more than four. The principle of one member, one vote, was adopted, and has since been the practically universal rule in workmen's co-operative societies of every class.

The good results obtained by the Rochdale Society led to many new societies being formed in various parts of the country, especially in Lancashire and Yorkshire. In 1847 the difficulty experienced by workmen in obtaining at reasonable prices unadulterated flour led to the formation of a society at Leeds for the purpose of carrying on a flour mill for the supply of pure flour to its members, who were by rule prohibited from purchasing any larger quantity than was needed for their own family requirements, and from selling to any persons bread or other goods made out of the society's flour. A few years later the society added a grocery and provision department, and subsequently other distributive and productive departments, and it is at the present time the largest retail distributive society in the United Kingdom, having a total membership of over 48,000 members, and an annual distributive trade of about $£ 1,500,000$, while it produces in its own manufacturing departments goods to an annual value of about $£ 300,000$.

About 1849 a group of young University men, working with the Rev. Frederick Denison Maurice in London, under the name of "Christian Socialists," commenced an active propaganda in favour of a novel form of Co-operation, to be carried on, not in the interest of the working-classes in general, with the object of ultimately forming self-supporting communities, as advocated by the co-operators of twenty years earlier, nor in the interests of the consumers, as were the societies based upon the lines of the Rochdale and Leeds Societies, but in the interests of the workers employed by the societies, it being proposed that these workmen should own the capital, manage the business, and divide among them the profits.

The source, from which this new co-operative ideal was derived, is to be looked for in the co-operative workshops founded in France at the time of the Revolution of 1848 , which had attracted the attention of one of the most active among the

No. 45.-vol. Xir. 
Christian Socialists, Mr. John Malcolm Ludlow (from 1875 to 1891 Chief Registrar of Friendly Societies), on a visit to Paris. Under the auspices of the Christian Socialists the "Society for Promoting Working Men's Associations" was formed in London, and an active propaganda was commenced in favour of the French type of Co-operation.

A "Code of Laws for an Association," issued by the Society just mentioned, sets forth as the objects of these Associations :-

1. To extend the principles and practice of associated labour.

2. To enable the associates and their families to receive all the net profits arising from their labour, after they shall have had a just allowance for the work done by them.

3. To work with other associations for a complete organisation of distribution, exchange, and interchange.

4. To establish conjointly with other associations, such institutions as may be beneficial to all of them. ${ }^{1}$

5. To support the other associations of the Union by our capital, credit, custom, influence and knowledge.

The model rules as to the division of profits provided that :-

"The profit shall be equally divided among all the associates in proportion to the time they have respectively worked. - of the profit shall be left to increase the capital of the association, which part shall bear interest at - per cent."

A certain part of the profit was also to be devoted to provident purposes (see Tracts on Christian Socialism, No. V, pp. 9-21).

From the Report of the Society above referred to, issued in 1852 , we learn that there were then in existence 10 associations of the new class, all formed in 1850-52, with a total membership of 185 , and an aggregate capital of $£ 13,560$, of which only $£ 471$ was subscribed by working-men, the balance being supplied by a few of the wealthier men among the Christian Socialists. A list of co-operative societies of all kinds published in 1854 showed that there were in operation at that time 194 societies, of which 144 were retail distributive stores and bakeries, 12 corn-mills, and 38 productive societies (14 in London, established under the direct guidance of the Christian Socialists, and 24 in the provinces). These productive associations were mainly formed on the French lines; most of them failed in a short time, the downfall of the London societies involving their middle-class promoters in considerable loss.

During the next few years a large number of co-operative societies (distributive and productive) were formed, mainly in the

1. Such as general store, benefit club, schools, library, museum, building: society, \&c. 
manufacturing districts, by the efforts of working-men, unaided (except by advice upon legal and other points) by their middleclass friends, whose influence, however, made itself felt in many instances in the character of the constitution adopted by societies for production.

At this time considerable difficulty was experienced by the distributive societies in obtaining supplies from the wholesale merchants. The shopkeepers, who had begun to feel the competition of the co-operative societies, had brought pressure to bear upon the merchants; and these traders now often declined to sell their goods to the co-operators. In order to remedy this state of things, attempts were made by the co-operators to establish wholesale agencies and societies; but as the existing law did not permit a co-operative society to invest capital in another society, these attempts to establish federations were unsuccessful. In 1862, however, an amendment of the law was made, giving wider powers to the societies, and the central federations of co-operators, which are now so prominent a feature of working-class Co-operation, were made possible, the English Co-operative Wholesale Society being founded in 1863, and the Scottish Wholesale Society in 1868. Both these organisations were started as consumers' associations on the ordinary lines of the English type of Co-operation, the retail societies, of which their membership consisted, dividing between them their surplus profits (after payment of a fixed rate of interest on capital) as "dividend on purchase."

Having now set forth the historical origin of the main forms of Co-operation, we may proceed to note the character of the ideals, which had up to this point been developed in the movement; and we observe that these ideals were of two perfectly distinct types. On the one hand, we find the societies formed in the interests of the consumers (the retail distributive societies, the Wholesales, the Corn Mills, and certain bread-baking societies), and, on the other, the societies formed in the interests of the producers ("productive associations"). In the consumers' societies, the English principle, that the society shall be managed by, and its profits shall go to, the purchasers, predominated; while among the productive associations the French ideal of the self-governing workshop, owned and managed by the employees, who are to take the profits of the business, prevailed.

As was natural, the presence within the co-operative movement of theories of Co-operation so widely divergent, gave rise to vigorous discussion among the co-operators. The advocates of 
the French type of Co-operation claimed that the consumers' societies (retail and wholesale) should leave the work of producing the goods required by the co-operators entirely in the hands of the " self-governing workshops," and that in all cases a share in profits should be allotted to the employees, in right of their labour, quite independently of any share to which they might be entitled as shareholders. These claims the great majority of working-men co-operators were not inclined to concede. By a number of middle-class well wishers of Co-operation, however, including Mill, Thornton, Fawcett, and other distinguished students of social questions, the merits of the French system were strongly urged. On the other hand, a different view was taken by E. V. Neale, a man of good social position, who had made great personal sacrifices in promoting the establishment of productive associations on the French model. In an article in The Co-operator, April 1866, p. 241, Mr. Neale wrote:-

The Co-operative Store is an institution through which the buyer supplies to himself that which he wants to buy-in other words, sells to himself . . . . What if we extend the same principle to the co-operative workshop . . . . Clearly if the consumer furnishes the capital by means of which that which he requires to consume can be made for him, if he is thus his own capitalist, the question of profit becomes a simple question of the arrangements most advantageous for the whole body of the consumers, as is the case now in the store.

There will cease to be a conflict of interest as regards these profits . . . . and with the cessation of this conflict, the difficult question of what is just in regard to them vanishes, not only as between buyer and seller, but also as between capitalist and workmen. For according to the principle laid down here, the profit is a fund distributable neither among capitalists nor workmen, but among the consumers from whose purchases it arises, while capitalists and workmen are both placed on the same footing of receiving each his wages, the capitalist as interest, the workmen as pay. . . . .

We would observe that the solution given by us of the question, what justice demands in respect to the division of profits, is a strong additional argument for the great importance of the Central Co-operative Stores, to which mainly co-operators must look as the means, first, of increasing the number of local stores and then of concentrating their influence so as to make it available for the support of manufacturing establishments in which the opposition of interest between the producer and consumer may disappear, and with its disappearance the question of what is just in respect to the distribution of profit may cease to embarrass us.

Thus, according to Mr. Neale, the system most in accordance with the true ideal of Co-operation, was that under which production should be organised by, and in the interests of, the consumers, and under this system no claim to a share in profits could justly be made on behalf of the employees. Mr. Neale's arguments, however, appear to have failed to convince the advo- 
cates of the French type of Co-operation of the error of their ways; and for many years the battle between the opposite schools of thought in the movement raged fast and furious. In the result, various branches of production were undertaken by the two Wholesale Federations and by a large number of retail distributive societies; and at the present moment about 89 per cent. of all co-operative production in Great Britain ${ }^{1}$ is carried on by societies formed exclusively by, and managed directly in the interests of, the consumers.

At the same time, although the consumers' societies have not seen their way, in deference to the views of the French school of co-operative thought, to abandon the work of production, yet, so far as profit-sharing is concerned, considerable concessions have been made to these views. Thus in the Government Report already referred to, we read that, in 1899,234 out of a total of 1,429 retail distributive societies in Great Britain gave up to their employees some share of their profits. Of the two Wholesale Societies, one only (the Scottish) practises profit-sharing; the great English Wholesale (though it at one time made experiments in this direction) does not allot any part of its profits to its employees.

The theories advocated by the French school of co-operators: not only contemplate that the employees shall receive at least a share of the profits of co-operative business, but also claim for them the right to control the management of the concern. But in this respect our consumers' associations, with scarcely an exception, have refused to make any concession to the foreign ideal. The employees of the retail distributive societies, although, if they happen to be members of the society, they can vote at the general meetings, are never elected to sit on the committee of management ; indeed the rules of most of the societies expressly prohibit their doing so. In the Scottish Wholesale the employees possess an infinitesimal voice at the general meeting of the Society, but are not allowed to be members of its committee; the much more important English Wholesale does not even admit its employees to membership in the society.

While, so far as concerns the consumers' associations, the ideal of Co-operation aimed at in their constitution and operations is for all practical purposes the same now as it was in the

${ }^{1}$ In all the statements made in the text with regard to the present position of Co-operation, excepting in the opening paragraph, Ireland is excluded. With the subject of Irish co-operative societies, which possess characteristics distinct in important respects from those found in any other co-operative associations in the United Kingdom, considerations of space make it impossible to deal here. 
beginning of the movement, on the other hand, in consequence of the changes in ideal, which have taken place, mainly in the course of the last ten years, the principles which at the present time prevail among the producers' associations bear but a fain resemblance to those advocated in the earlier days of co-operative production. Thus, while in 1884 the "Labour Association" was formed with the express object of " assisting working men to organise themselves for mutual self-employment" (Report of Co-operative Congress, 1885, p. 20), in 1897 we find that Mr. Vivian, the Secretary of the Labour Association, speaking as its official representative at the third Congress of the International Co-operative Alliance at Delft, emphatically declared that "In England, experiments of a ridiculous nature had been made. In the early days of the movement, the ideal aimed at was to have workshops which should be self-governing; the capital and all the profits were to belong to the workers. But, now-a-days, this ideal has been abandoned " (Compte Rendu, p. 138).

Every student will remember the enthusiastic hopes aroused in the mind of John Stuart Mill by these "experiments of a ridiculous nature." Mill wrote: "The form of association which, if mankind continue to improve, must be expected in the end to predominate, is not that which can exist between a capitalist as chief, and work-people without a voice in the management, but the association of the labourers themselves on terms of equality, collectively owning the capital with which they carry on their operations, and working under managers elected and removable by themselves" (Political Economy, sixth edition, p. 352). Now let us contrast with Mill's ideal co-operative association the actual facts in relation to co-operative productive associations as shown by the Report already referred to (p. xxix). So far from the productive society of to-day being the "association of the labourers themselves," we find that of the total individual membership of these associations in Great Britain at the end of 1899, 15 per cent. only consisted of persons employed by the associations. So far from the labourers "collectively owning the capital," we learn that "these employees held amongst them about 9 per cent. of the total share and loan capital of the associations."

With the ideal of the labourers "working under managers elected and removable by themselves," contrast the actual facts : "So far as the particulars can be obtained, about a quarter of the total production by these associations is due to associations, the managing committees of which are effectively controlled by 
the employees, and about two-thirds to associations, the management of which is practically in the hands of persons other than the employees." The ideal pursued in the early productive associations was that the whole of the profits should belong to the workers; but the figures given in the Report show that, out of a total profit of $£ 47,259$, the division of which was returned by the productive associations in Great Britain (other than corn-mills and the associations comprised in the "Bread-making and other foods" group, nearly all of which are, like the corn-mills, consumers' associations), the share of the workers in these profits amounted to no more than $£ 14,944$, or $31 \cdot 6$ per cent., capital taking $£ 19,562$, or 41.4 per cent., and the remainder, amounting to $£ 12,753$, or 27 per cent., going to the customers of these societies as a dividend on purchases.

If, as is clear, the modern productive associations are not self-governing workshops owned and managed by the work-people employed in these workshops, in whom (it will be asked) is the ownership and management of these undertakings actually vested? So far as ownership is concerned, the figures given in this Report show that, taking together the whole of the productive societies in Great Britain (other than corn-mills and breadmaking, \&c., societies) as to which information on this point is furnished, their aggregate capital (share and loan) at the end of 1899 amounted to $£ 603,313$, of which $£ 71,969$ (11.9 per cent.) was owned by employees, $£ 197,002$ (32.7 per cent.) by other individuals, and $£ 230,697$ (38.2 per cent.) by other co-operative societies-almost without exception retail distributive societies-the balance of $£ 103,645$ consisting of bank overdrafts and loans from non. members.

With regard to the management of our productive associations, here again the large share taken by the consumers' retail societies is worthy of remark. For out of a total of 1,154 committeemen in the 121 societies in Great Britain, as to which the Report gives information, no less than 218 are stated to be "representatives of societies"; while the productive societies, in which the influence of the retail distributive societies is absolutely paramount, are concerns of great importance. Out of the entire output of the 132 " associations established mainly in the interests of the employees," "we find that " 44 per cent. was attributable to 20 associations in which the whole or majority of the members of management committees were representatives of retail distributive societies."

It is evident that the amount of influence actually possessed 
by the employees in the conduct of the affairs of co-operative societies to-day, is, when compared to that assigned to them by the early ideals of Co-operation which the Christian Socialists borrowed from France, almost insignificant. Nor should it be supposed that this change is entirely due to the fact that the productive societies required the assistance of the rich consumers' associations, and in order to obtain that assistance, have had to allow these associations a constantly increasing share in control. There can be no question that this revolution in the practice of Co-operation corresponds closely with a deliberate alteration in the ideal pursued by the advocates of co-operative productionan alteration which can best be explained by setting forth textually the official declaration made by the most active organisation concerned with promoting the new system of Co-operation. This system; to which the name of Labour Co-partnership is given, is officially defined in the journal of the Labour Association as " the system under which, in the first place, a substantial and known share of the profit of a business belongs to the workers in it, not by right of any shares they may hold, or any other title, but simply by right of the labour they have contributed to make the profit; and in the second place, every worker is at liberty to invest his profit, or any other savings, in shares of the society or company, and so become a member entitled to vote on the affairs of the body which employs him."

While, as will be seen, the whole of the profits are no longer claimed for the employees, the share in control, which is now asked for them, is of an extremely modest character, ${ }^{1}$ and such as

1 The position occupied by the employees of a co-operative productive association organised upon the lines, which the advocates of Labour Co-partnership desire to see adopted, may be illustrated by reference to the rules drawn up by the Labour Association for the "Ideal Clothiers, Ltd.," a society registered under the auspices of that propagandist organisation in 1900. The shares of this association are of two kinds, ordinary shares of the nominal value of $£ 1$ each, and "accumulated shares" of the nominal value of one penny each, the latter being shares allotted to employees of the society by virtue of the rule, which requires that the share in profits coming to an employee shall be credited to him in shares until he holds in such shares an amount equivalent to his wages for six months. These accumulated shares do not confer upon their holders any right whatever of voting at general meetings, or of being elected to serve on the "Board of Directors." So far as concerns the general meetings, the old democratic rule of "one man, one vote" is abandoned. A shareholder is not allowed to vote at all unless he is the holder of fully paid-up ordinary shares to the value of $£ 10$, and is given an additional vote for each complete $£ 50$ of additional fully paid-up shares owned by him. With regard to the composition of the "Board of Directors," which is to consist of the president, secretary, manager, and seven members, it is expressly provided that "of these seven members, not more than four (or not more than three-if the president is also an employee) shall be elected by the members employed by the 
to be quite consistent with the virtual predominance of the consumers' societies in the management of the productive associations. Indeed, the advocates of Labour Co-partnership, while they welcome the retail distributive societies as members of the "productives," on account of the capital which they bring in, and the custom which they secure for these associations, at the same time entirely approve of the prominent part now taken by the retail societies in the management of the affairs of the productive associations, which thus enjoy the advantage of the administrative ability and business experience possessed by the distributive societies.

Enough has now been said to indicate the new trend of the co-operative ideals. It will be seen that the co-operative productive society, instead of being, as originally contemplated, an autonomous association of self-employed workmen, owning the capital, managing the business, and taking the profits, is more and more every day becoming, in the main, a federation of consumers' associations, in the ownership and management of which the work-people employed by the society have but a small part. Thus the victory of the English ideal of organisation by the consumers over the French ideal of organisation by the producers appears now to be, on the whole, all but complete.

$\mathrm{X}$

society. The remainder of the seven shall be elected by the members not so employed." At the same time, the qualification required for eligibility as a director is made of such a nature that few of the employees are likely to fulfil the conditions laid down. For "when the paid-up ordinary share capital of the society exceeds $£ 1,000$ (this limit has already been passed) no, person shall be eligible for the Board unless he has at least 20 fully paid-up ordinary shares in the society, and he shall pay up not less than £5 additional share capital for each complete $£ 1,000$ of paid-up ordinary shares in the society."

** The writer of the above article has been for many years intimately connected with the Co-operative movement. His statements are based on personal observation and original authorities.-Editors. 